\title{
Gorontalo
}

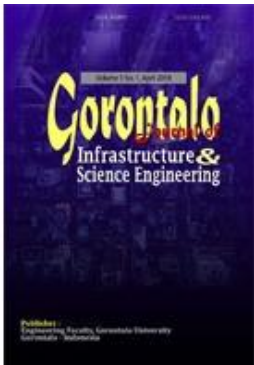

\section{Analisis Potensi Pengembangan Pembangkit Listrik Tenaga Mikrohidro Di Kabupaten Bone Bolango}

\author{
Nurhayati Doda ${ }^{1)}$ dan Herdi Mohammad ${ }^{2}$ \\ 1)Teknik Sipil, Fakultas Teknik Universitas Gorontalo \\ e-mail : yati.doda@gmail.com \\ 2)Teknik Sipil, Fakultas Teknik Universitas Gorontalo \\ e-mail : herdi.muh@yahoo.co.id
}

\begin{abstract}
Energy is a major need in human life, but along with the population growth will be the availability of electrical energy especially that from fossil fuels are being reduced and insufficient for the needs of small-scale electric power listrik.Pembangkit potential as an alternative to fossil energy sources namely renewable micro hydro power plant availability of electricity in remote villages in the district of Bone Bolango is alarming, so it was done research on Analysis of Potential Development of micro hydro power plant (MHP) in Bone regency Bolango. This study aims to provide an overview and preliminary information on the potential of hydropower as a basis for planning and development of micro hydro power plant. In this research will be outlined potential sites for the development of MHP with power potential, specifications turbindan civilian buildings. Measurement of power was awakened by the amount of streamflow in Mongiilo Desa Ulu Subdistrict Bolango Bone Bolango District. Debit analyzed based on observation of the flow rate by using a current meter. From the analysis of the amount of power potential in getting aroused in the research area of 289,935Kw with ideal flow $12.14 \mathrm{m3} / \mathrm{sec}$, the average efficiency of $65 \%$ with the plan fell $3.75 \mathrm{~m}$ high. This power is sufficient magnitude elektrifitas needs of residents in the study area that is equal to $65 \mathrm{~kW}$.
\end{abstract}

Keywords: Microhidro,Electrical Power

\section{PENDAHULUAN}

Energi merupakan suatu kebutuhan utama dalam kehidupan manusia.Semakin maju suatu Negara, semakin besar energy yang dibutuhkan.Bila ditinjau dari sumber pengadaan energy dunia saat ini, sumber migas merupakan sumber utama. Sumber migas yang terdapat di bumi sangat terbatas dan pada suatu saat akan habis. Ketergatungan akan energi bahan bakar fosil seperti batu bara, minyak bumi dan gas akan semakin meingkat.

PLTMh adalah suatu pembangkit Listrik Tenaga Air (PLTA) low head dengan kapasitas kurang dari 500 Kilo Watt $(\mathrm{kW})$.Potensi total PLTMh di Indonesia tahun 2002 adalah sebesar 500 Mega Watt $(\mathrm{mW})$, yang sudah dimanfaatkan 
baru $21 \mathrm{MW}$. Potensi tersebut sebenarnya masih akan meningkat sejalan dengan intensitas studi potensi yang dilakukan untuk menemukan lokasi-lokasi baru.

Listrik merupakan salah satu kebutuhan yang sangat penting bagi kehidupan manusia. Tanpa adanya listrik, akan sulit bagi kita untuk mengembangkan suau aktivitas. Salah satu contoh ialah sulit terjangkau oleh PLN, namun demikian wilayah ini memiliki potensi sumber daya air yang relativ stabil sepanjang tahun karena berada dekat kawasan hutan lindung yang merupakan salah satu Taman Nasional di Indonesia.Aktivitas masyarakat setempat masih sangat sulit berkembang karena tanpa adanya pasokan listrik yang memadai walaupun saat ini sebagian kecil masyarakatnya sudah mendapatkan pasokan listrik tenaga surya. Sehingga itu rencananya di wilayah ini akan dikembangkan pambangkit listrik ramah lingkungan, yaitu Pembangkit Listrik Tenaga Mikrohidro (PLTMh) sebagai sumber pasokan energinya. Sumber air untuk PLTMh akan memanfaatkan aliran sungai yang terdapat di kawasan hutan lindung di wilayah Desa Mongiilo Bone Bolango.

Pembangkit listrik skala kecil yang potensial adalah Pembangkit Listrik Tenaga Mikro Hidro (PLTMH), yang merupakan suatu implementasi dari Green Energy Initiative yaitu mendorong energi terbarukan, efisiensi energi dan energi bersih. Program pembangunan PLTMH bertujuan untuk mendorong kegiatan ekonomi masyarakat terutama di lokasi yang potensial namun belum dioptimalkan. PLTMH memiliki beberapa kunggulan dibanding dengan pembangkit listrik lainnya, bersih lingkungan, tidak konsumtiv terhadap pemakaian air, lebih awet (tahan lama/long life), biaya operasinya lebih kecil dan sesuai untuk daerah terpencil

Berdasarkan kondisi tersebut maka dilakukan penelitian dengan focus riset untuk memberikan gambaran dan informasi awal mengenai potensi tenaga air sebagai dasar dalam perencanaan dan pembangunan pembangkit listrik tenaga mikro hidro (PLTMh). Dalam riset ini akan dijabarkan lebih detail lokasi yang potensi untuk pengembangan PLTMh, potensi daya, spesifikasi turbin dan bangunan sipil. Dengan maksud memberikan manfaat untuk membuat rancangan pembuatan Pembangkit Listrik Tenaga Mikro Hidro di daerah untuk dalam rangka peningkatan ketersediaan energy listrik untuk pedesaan. 


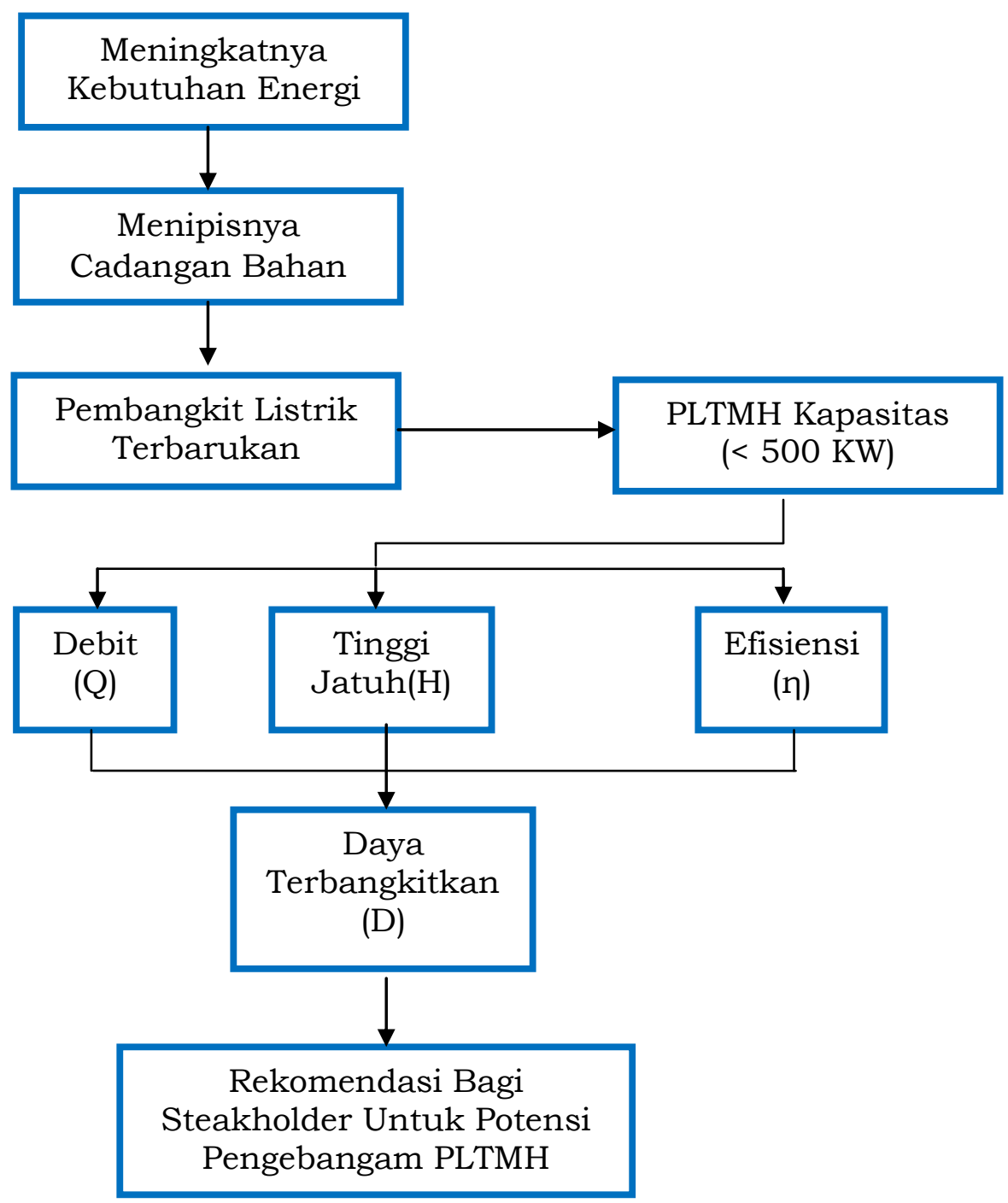

Gambar 1. Kerangka Pikir

\section{KAJIAN TEORI}

\subsection{Krisis Energi}

Energi listrik merupakan energy yang penting sebagai penunjang aktivitas hidup manusia. Fakta menunjukkan bahwa sebesar $56 \%$ atau 1,7 mulyar penduduk dunia tidak mendapatkan akses terhadap listrik. Demikian pula di Indonesia, distribusi jaringan listrik masih belum merata. Disisi lain Indonesia kaya akan energy terbarukan yang berasal dari laut, karena 2/3 luas wilayah Indonesia adalah laut. Jadi solusi bagi warga-wagra yang tinggal di daerah terpencil adalah memanfaatkan energy luar. 


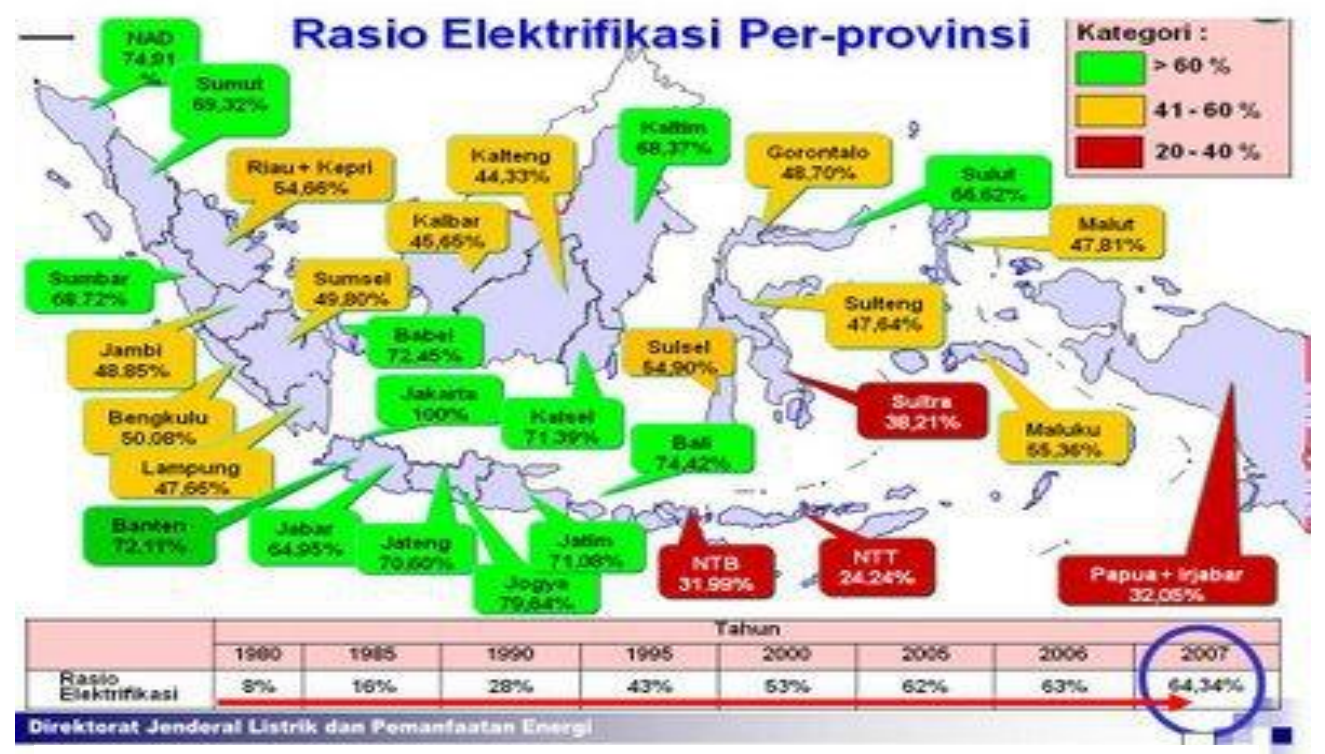

Gambar 2. Rasio Elektrifikasi Per-Provinsi

Sumber: Direktorat Jendral Listrik dan Pemanfaatan Energi

Departemen Energi dan Sumber Daya Mineral, 2008

\subsection{Pembangkit}

Khusus di Indonesia pemanfaat potensi energy terbarukan seperti air, angin, biomassa, dan lainnya sampai saat in belum optimal. Misalnya untuk kasus energy air, sampai dengan tahun 2004, kapasita dari pemanfaatan tenaga air hanya mencapai 4.200 MW dari $75,67 \mathrm{GW}$ potensi yang ada atau hanya 5,55\%.

\begin{tabular}{|l|c|c|c|}
\hline \multicolumn{1}{|c|}{ Sumber Energi } & $\begin{array}{c}\text { Potensi } \\
(\mathrm{MW})\end{array}$ & $\begin{array}{c}\text { Kapasitas } \\
\text { Terpasang } \\
(\mathrm{W})\end{array}$ & $\begin{array}{c}\text { Pemanfaatan } \\
(\%)\end{array}$ \\
\hline Air & 75.670 & 4.200 & 5,550 \\
\hline Biomassa & 49.810 & 302,4 & 0.607 \\
\hline Panas Bumi & 27.000 & 800 & 2,900 \\
\hline Mini/mikro hidro & 458.75 & 84 & 18,30 \\
\hline Energi Cahaya & 156.487 & 8 & 0,005 \\
\hline Energi Angin & 9.280 & 0,50 & 0,005 \\
\hline Total & $318.711,75$ & $5.391,9$ & 27,427 \\
\hline
\end{tabular}

Sumber :Blueprint Pengelolaan Energi Nasional 2005-2025

\subsection{Kondisi Geografi dan Potensi Energi Terbarukan}

Kabupaten Bone Bolango merupakan salah satu kabupaten di Provinsi Gorontalo, secara geografis mempunyai luas $1.984,58 \mathrm{Km} 2$ atau $16,24 \%$ dari luas total Provinsi Gorontalo. Kabupaten Bone Bolango di bagi menjadi 18 kecamatan, terdiri dari 166 kelurahan/desa.Kecamatan dengan luas terbesar adalah Kecamatan Suwawa Timur sedangkan kecamatan dengan luas daerah terkecil yaitu Kecamatan Bulango Selatan.

Kecamatan Bone Ulu Kabupaten Bone Bolango mempunyai sungai besar yang dapat dimanfaatkan potensi airnya untuk Pembangkit Listrik Tenaga Mikrohidro. 
Berdasarkan posisi geografisnya, Kabupaten Bone Bolango berbatasan langsung dengan Kabupaten Bolaangmongondow (Sulawesi Utara) dan Kabupaten Gorontalo Utara di sebelah utara. Sementara di sebelah timur berbatasan dengan Kabupaten Bolaangmongondow Selatan, di sebelah selatan berbatasan dengan Kota Gorontalo dan teluk Tomini, di sebelah barat berbatasan dengan Kecamatan Telaga, Kota Selatan dan Kota Utara.

\subsection{Keunggulan}

Sifat dari energy PLTMh ini adalah tak terhabiskan atau terbarukan dengan keunggulan antara lain PLTMh bias beroperasi sehari penuh karena air tidak tergantung siang dan malam, Pengoperasian PLTMh tidak memerlukan biaya yang mahal, serta keunggulan lainnya.

Ada beberapa alasan mengapa PLTMH merupakan pilihan yang tepat :

1. Indonesia kaya akan hutan sehingga kaya akan air

2. Membangun PLTMH berarti melestarikan sumber daya air

3. PLTMH bisa beroperasi sehari penuh karena air tidak tergantung siang dan malam hari

4. Alat-alat PLTMH sudah bisa diproduksi di dalam nergi dan peralatan pengganti bisa di dapat di kota-kota besar di Indonesia

5. PLTMH lebih awet, jika dipelihara dengan baik, dibanding pembangkit listrik yang lainnya seperti PLTS, PLTU dll.

6. Pengoperasian PLTMH tidak memerlukan biaya yang mahal (dibandingkan dengan pengoperasian generator disel)

\subsection{Head}

Head bersih adalah selisih antara head ketinggian kotor dengan head kerugian di dalam sistem pemipaan pembangkit listrik mikrohidro.

\subsection{Debit}

Debit aliran sugai merupakan volume air sungai yang mengalir dalam satuan waktu tertentu. Pengukuran debit debit sungai adalah dengan mengukur luas penampang basah, kecepatan aliran dan tinggi muka air sungai tersebut dengan menggunakan persamaan :

$$
Q=V x A
$$

Dengan $\mathrm{Q}=$ Debit $\left(\mathrm{m}^{3} / \mathrm{s}\right)$

$\mathrm{V}=$ Kecepatan aliran $(\mathrm{m} / \mathrm{s})$

$\mathrm{A}=$ Luas penampang sungai

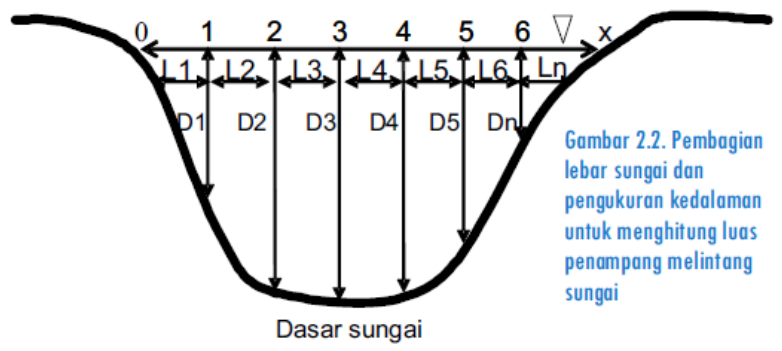

Gambar 3. Pembagian Luas Sungai dan Pengukuran Kedalaman 
2.7. Daya Bangkitan

$$
\begin{aligned}
\mathrm{Pa}=Q . \rho . g . H & \ldots \ldots \ldots \ldots \ldots \ldots . . . \\
\text { Dengan } \mathrm{Pa} & =\text { Daya } \\
\mathrm{Q} & =\text { Debit } \\
\rho & =\text { Kerapatan air } \\
\mathrm{g} & =\text { Gaya gravitasi bumi } \\
\mathrm{H} & =\text { Tinggi jatuh air }
\end{aligned}
$$

\section{PERENCANAAN CAMPURAN BETON}

\subsection{Alat yang digunakan}

a. Current meter

b. Stopwatch

c. Meterean

d. Tali

e. Tongkat

f. GPS

g. Pensil

h. Kertas

i. Waterpass

\subsection{Survey dan Pengukuran}

Survey potensi air sebagai dasar dalam perencanaan PLTMh dalam empat tahapan, yaitu :

a. Penetuan lokasi

Penentuan lokasi dilakukan dengan menyusuri sungai yang berada di daerah kecamatan Bolango Ulu.Perekaman jalur saluran pembawa dari bendungan ke bak penampung.

Perekaman jalur saluran pembawa dari bendungan ke bak penampungan dan jalur pipa panstock dari bak penampungan ke rumah turbin, kita dapat memanfaatkan fitur tracks yang terdapat pada GPS. Fitur Tarcks menciptakan jejak elektronik atau "catatan jejak" pada map page selama bepergian. Catatan jejak tersebut berisi informasi tentang point-point sepanjang jalurnya. Termasuk waktu, lokasi, ketinggian dan kedalaman. Catatan jejak akan merekam semua informsi yang diperlukan sesaat setelah alat ini menentukan posisi lokasi yang dikirimkan oleh minimal dua sinyal satelit.

b. Pengukuran tinggi jatuh air

Pengukuran ketinggian menggunakan selang waterpass.pengukuran bedatinggi juga dilakukan secara manual menggunakan meteran dengan Metode Spirit Level and String (papan Watrpass). Metode ini hampir sama dengan pengukuran beda ketinggian menggunakan selang waterpass namun perbedaannya adalah pada Metode Spirit Level and String menggunakan batang waterpass. Metode Spirit Level and String melakukan pengukuran beda ketinggian antara dua titik dengan menggunakan bantuan tiang, tali dan batang waterpass untuk melihat kelurusannya secara horisontalo. Pengukuran head secara manual menggunakan meteran. 
c. Pengukuran debit air

Pengukuran debit air didasarkan pada hasil pengukuran kecepatan aliran terhadap luas penampang sungai

d. Perhitungan potensi daya terbangkitkan

Berdasarkan data yang ada, dilakukan analisis terhadap daya bangkitan

\subsection{Sumber Data}

a. Data Primer

1. Debit aliran didapatkan dengan pengukuran kecepatan aliran dan luas penampang.

2. Ketinggian didapatkan berdasarkan hasil pengukuran lapangan

b. Data Sekunder

1. Data debit andalan yang diperoleh dari BWS II

2. Data jumlah penduduk dari BPS Bone Bolango

\subsection{Analisis Data}

a. Debit aliran dianalisis berdaarkan persamaan 1

b. Daya terbangkitkan dianalisi berdasarkan bersamaan 2

\subsection{Diagram Alir Penelitian}

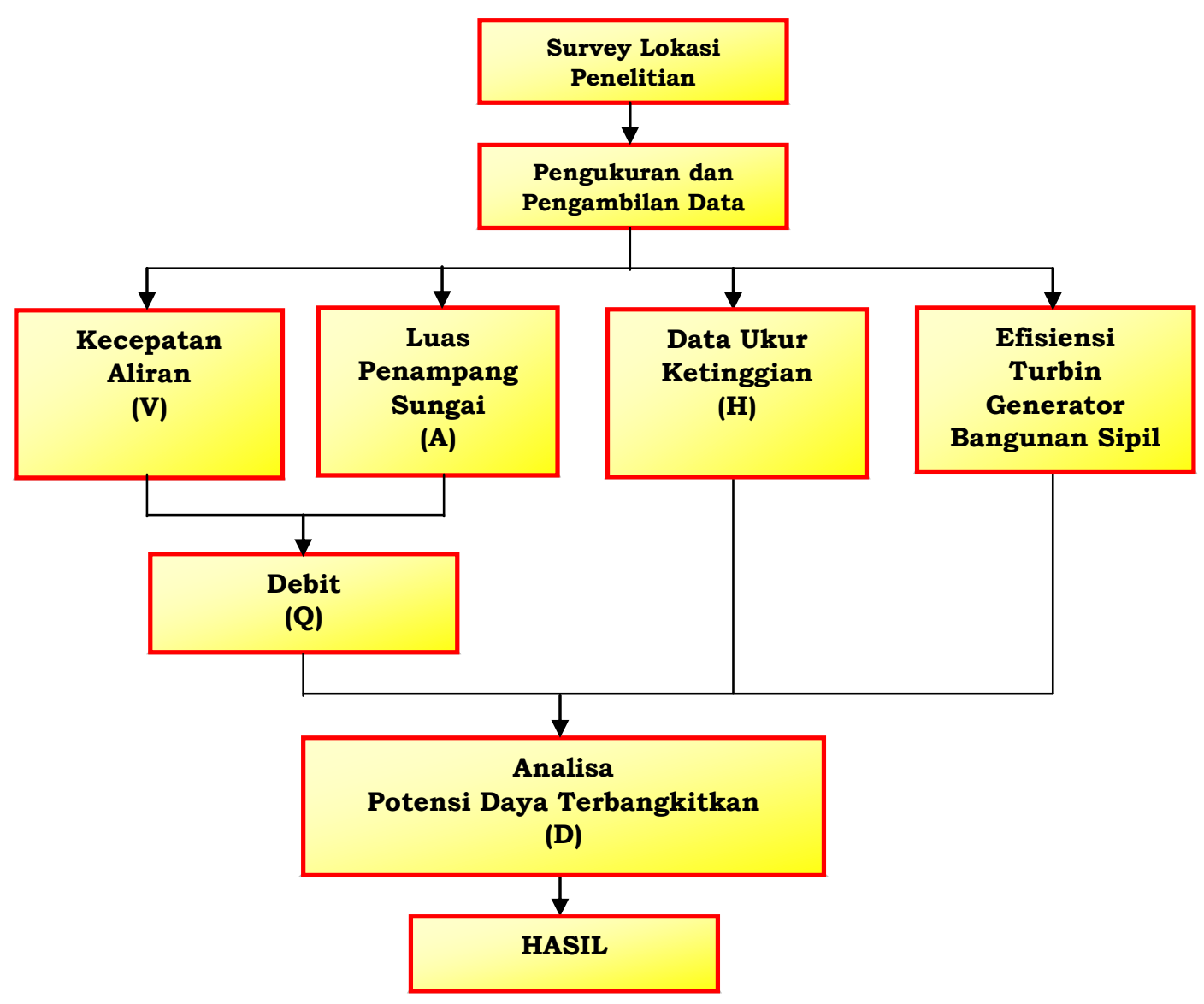

Gambar 4. Bagan Alir Penelitian 


\section{HASIL DAN PEMBAHASAN}

Bagian ini menyajikan hasil penelitian. Hasil penelitian dapat dilengkapi dengan tabel, grafik (gambar), dan/atau bagan. Bagian pembahasan memaparkan hasil pengolahan data, menginterpretasikan penemuan secara logis, mengaitkan dengan sumber rujukan yang relevan.

\subsection{Hasil Penelitian}

a. Potensi Debit air Sungai Bolango Kabupaten Bone Bolango untuk PLTMh berdasarkan nilai kecepatan dengan hasil pengukuran di lapangan dengan rata-rata kecepatan $1,66 \mathrm{~m} / \mathrm{s}$ dan total luas penampang sungai sebesar 7,34 $\mathrm{m} 2$ sehingga mendapatkan nilai debit:

$$
\begin{aligned}
& Q=V \times A \\
& Q=(1,66)(7,34) \\
& Q=12,14 \mathrm{~m}^{3}
\end{aligned}
$$

\section{Efisiensi Mikrohidro}

Perhitungan daya menggunakan hokum Newton dan persamaan Bernouli merupakan perhitungan standar atau awal. Perhitungan tersebut mengabaikan beberapa sistem sehingga tidak diketahui berapa daya yang hilang ketika energy potensial air dirubah menjadi energy listrik. Besarnya energy yang hilang dipengaruhi oleh beberapa hal, antara lain yaitu:

1. Efisiensi Konstruksi Sipil 95\%

2. Efisiensi Turbin $80 \%$

3. Efisiensi Generator $85 \%$

Sehingga untuk efisiensi total adalah:

$=0,95 \times 0,80 \times 0,85$

$=0,65$ atau $65 \%$

b. Daya Terbangkitkan

Dari besarnya debit yang dihasilkan, maka besarnya daya terbangkitkan adalah:

$\mathrm{D}=9,8 . \mathrm{Q} \cdot \mathrm{H} \cdot \eta$

$\mathrm{D}=289,935 \mathrm{Kw}$

c. Kondisi Sosial dan Kebutuahn Listrik Masyarakat di sekitar aliran sungai sebagian besar adalah masyarakat petani dengan pola penyebaran perumahan penduduk jarang dan tidak padat, dengan jumlah rumah tangga rata-rata kurang dar 20 rumah per kilometer, sehingga dengan adanya PLTMh ini maka pembagian pembebanan dapat berupa pembebanan penerangan dan alat rumah tangga serta peralatan elektrifikasi pertanian dapat tercukupi. Kebutuhan daya untuk penerangan dari perhitungan di atas rata-rata 20 RT dimana prediksi per Rumah Tangga $100 \mathrm{~W}$ adalah 2000 Watt atau $2 \mathrm{Kw}$. Untuk peralatan rumah tangga dan peralatan elektrifikasi pertanian da[at dilakukan dengan pengaturan pembebanan yang dapat disepakati seperti mana di siang hari penerangan dan sebagian alat rumah tangga tidak difungsikan sehingga dapat dikompromikan penggunaannya untuk alat-alat elektrifikasi pertanian.

Berdasarkan hasil analisa didapatkan total kebutuhan daya sebesar 450 watt tegangan sistem 220 volt untuk setiap kepala rumah tangga (KK) dengan jumlah KK di Desa Mongiilo Kecamatan Bolango Ulu berdasarkan 
Data Sekunder dari BPS Bone Bolango Tahun 2015 sebesar 145 KK, sehingga perkiraan kebutuhan daya sebesar :

45 watt $\mathrm{x} 145 \mathrm{kk}=65.250$ watt

Atau 65 KW

\subsection{PEMBAHASAN}

Berdasarkan hasil pengukuran dan analisa terhadap data ukur yang diperoleh, maka dapat dideskripsikan hasil penelitian tersebut adalah sebagai berikut:

a. Analisa terhadap debit aliran pada bendung di Sungai Bolango didapatkan berdasarkan pengukuran terhadap kecepatan aliran dengan menggunakan Current meter dengan rata-rata kecepatan aliran (V) sebesar 1,66 m/s, luaspenampang sungai (A) sebesar 7,34 $\mathrm{m} 2$, sehingga didapatkan besarnya debit $(Q)$ yang mengalir di sungai tersebut adalah $12,14 \mathrm{~m} 3 /$ detik

b. Berdasarkan hasil analisis evisiensi terhadap turbin, bangunan sipil dan generator didapatkan nilai evisiensi sebesar 65\%

c. Dari besarnya debit (Q) dengan rencana tinggi jatuh (Head) sebesar 3,75 $m$ serta memperhitungkan nilai efisiensi 65\%, mka didapatkan besarnya Daya terbangkit adalah $289,934 \mathrm{Kw}$

d. Kondisi social dan budaya masyarakat dengan penggunaan fasilitas kelistrikan, didapatkan hasil analisis terhadap kebutuhan energy dengan kebutuhan setiap rumah tangga atau kepala keluarga (KK) sebesar 450 watt

e. Dari data kependudukan umlah kepala rumah tangga di Desa Mogiilo Kecamatan Bolango Ulu sebanyak $145 \mathrm{KK}$, sehingga kebutuhan daya sebesar 62.250 Watt atau 62,25 KW.

\section{KESIMPULAN DAN SARAN}

Berdasarkan hasil penelitian maka dapat disimpulkan bahwa hasil analisa terhadap potensi pengembangan Pembangkit Lisrik Tenaga Mikrohidro dengan debit (Q) $12,14 \mathrm{~m} 3 / \mathrm{s}$ efisiensi $65 \%$ dan rencana tinggi jatuh (Head) 3,75m, didapatkan memiliki potensi Daya terbangkitkan sebesar 289,935 KW. Besar daya ini sangat mencukupi kebutuhan listrik masyarakat Bolango Ulu dengan perkiraan kebutuhan sekitar 62,25 KW, dengan kebutuhan setiap KK sebesar 450 watt.

\section{REFERENSI}

Adel welblog's, Pembangkit Listrik Tenaga Mikro Hidro, 10 Juni 2008

Andreas, Global Energy Governance, ISBN 978-08157-0343-3, Global public Policy Institute, , 2010

Blue Print Pengelolaan Energi Nasional, 2005.

http:/ / www.scribd.com/doc609979/Republik Indonesia

Bone Bolango Dalam Angka 2015, Katalog No. 1102001.7504, BPS Bone Bolango

David Lindsley, Power Point Control and instrumentation, Cambridge Universitry Press, England, ISBN 0852967659, 2005

DESDM, Kebijakan Pengembangan Energi Terbarukan dan Konservasi Energi (Energi Hijau), Jakarta 2003 
Fox.R.W, Me Donal. A.T \& Pritchard. P.J. (2011), Introduction to Fluid Mechanics Eighth Edition, Purdue University.

Harvey, Adam, "Micro Hydro Design Manual - A Guide to small scale water power scheme", (1993), ITDG Publishing, London, UK

Jhon Tabak, Energy and the Environment, Facts on file New York, ISBN 97808160-7082-4, 2009

Mockmore, C \& Merryfield, Fred, The Banki Water Turbine, Journal www.bankiwaterturbin.com

Sulasno, Teknik dan Sistem Distribusi Tenaga Listrik. Badan Penerbitan UNDIP, Semarang, 2001. 